\title{
The Gay Novel and the Gay World
}

\author{
GUY DAVIDSON
}

\begin{abstract}
In a recent review essay, J. Daniel Elam charts the emergence of "gay world literary fiction," a subgenre of the category "world literature," which over the last twenty years or so has become both a marketing strategy for publishers and a "disciplinary rallying point of literary criticism

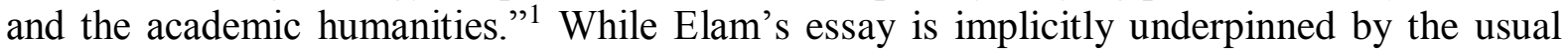
disciplinary understanding of world literature (fiction from potentially anywhere in the globe, translated into English, and studied comparatively), its focus is narrowed to the "gay world" within the planetary world - a putatively homogenous, transnational gay subculture enabled by digital connectivity and the flows of global capital. This new gay world is, according to Elam, characterized by atomization: "From Sofia to Shanghai, authors of gay fiction describe a collection of scattered and isolated individuals, needy but incurious." The situation has emerged from the "curious paradox" that "visibility and acceptance" have "made life better" for many gay men "at the cost of community and identity." "Gay visibility, with its attendant politics of respectability" has occurred at the expense of older subcultural institutions like "the gay bar, the bathhouse, the piano bar, and cruising areas," rendering the gay community "a banally knowable object rather than the product of a passionately forged experience of selfmaking. In place of the urgent longings of 20th-century queer literature, one encounters a peculiar form of worldly, muted yearning. So-called gay world literature emerges from a global community that isn't a community at all."
\end{abstract}

Elam's account typifies the stance of contemporary queer studies toward visibility, offhandedly acknowledging the benefits it has brought before hastening to elaborate its pitfalls. During the first flush of queer theory in the 1990s, queer critics tended to associate visibility with social control — as manifesting Foucauldian power/knowledge - and contrasted it with an idealized, untrammeled queer subjectivity. Judith Butler, for instance, in a very influential 1991 essay, subjected the idea of visibility to high-beam deconstruction, arguing that there "can be no transparent or full revelation ... offered by 'lesbian' or 'gay,", and rhetorically asked whether the failure of "gayness" to reveal fixed truth is "to be valued, a site for the production of values, precisely because the term now takes on a life that cannot be, can never be, permanently controlled?"2 For Lee Edelman, in an equally generative text, visibility is situated as an example of "the policial regulation of social identities," and his own analytic project is contrastively conceived as a work of "resistance" to the "reification" supposedly entailed by open gayness. ${ }^{3}$ The attitude of 1990 s queer studies to visibility is perhaps most astringently summarized in Leo Bersani's assertion that "visibility is a precondition of surveillance, disciplinary intervention, and, at the limit, gender cleansing.... Once we agreed to be seen, we also agreed to being policed." "Elam differs from these drastic pronouncements in that he equates visibility with banality, respectability, and loss of communal identity rather than policing and surveillance, and in this respect no doubt his account reflects the changes in LGBT life that have taken place since the 1990s (increasing social tolerance, the legalisation of gay marriage, and so on). Yet the reflexive oppositional stance is maintained, with contemporary visibility contrasted with a (pre-visible? semi-visible?) community centred on bars and cruising areas. Elam's chronology is rather vague; and the undoubted, and increasing, impacts of globalisation notwithstanding, his account of an overriding sameness to the world gay subculture "from Sofia to Shanghai" is also surely a too-hasty flattening of cultural and national differences. For Elam, as for many commentators on contemporary globalisation, the advent 
of digital communication seems to make the crucial, definitive difference. He contrasts a predigital gay world characterised by face-to-face encounters with the supposedly alienated contemporary dispensation. While the pre-digital situation straddles both the before and after of gay liberation, conventionally dated to the 1969 Stonewall Inn riots in New York City, Elam's piece rhetorically lines up with the not-uncommon queer romanticisation of the preliberated past, in which the necessity of hiding homosexuality supposedly generated a subcultural richness and energy that has now been fatally compromised by, or altogether bargained away in the interests of, social tolerance and visibility. ${ }^{5}$

Though I am sceptical of Elam's claims, his piece also provocatively opens up key concerns of this essay, which is a preliminary effort to think through the relations between what I tentatively and cautiously call "the gay novel" and "the gay world" —understood both as a cohesive subculture and an instance of global flow - in the mid-century, pre-liberation period that, for Elam, contrasts so sharply with the present day. Specifically, I am interested in how a tradition of the gay novel from Aotearoa New Zealand might be theorised in relation to transnationalism, and what implications this theorisation might have for gay or queer literary studies. In the second half of this essay, I offer, by way of a case study, a brief reading of the 1959 novel A Way of Love by James Courage (1903-63). Courage was born in Christchurch into a wealthy sheep farming family, but lived most of his adult life in London, where he published plays, short stories, poetry, and eight novels. I will propose that Courage's novel presents an exemplary manifestation of what Elam calls the "urgent longings of $20^{\text {th }}$-century queer literature," but also that these urgent longings include the desire for visibility. There is, I suggest, a continuity between twentieth-century subcultural formations and their present-day manifestations that Elam disavows in his opposition between the "passionate" gay underground of years past and the contemporary banality of visibility. ${ }^{6}$

My relation to the set of interests I've outlined is somewhat oblique, but also I hope productive. I am a New Zealander by birth and upbringing but I have lived in Australia for many years and my expertise as a researcher is in gay and lesbian American writing rather than queer literature from New Zealand - or Australia, for that matter. I cannot claim a deep knowledge of the literature that might be classified as gay or queer that comes from New Zealand or that may be tied back to it. However, I am intrigued by questions of tradition and canonicity in relation to gay literature, an intrigue that has been quickened by recent experience in constructing or at least modifying "traditions" for two companion chapters that survey American gay and lesbian literature. If tradition is always "selective," as Raymond Williams argued in his landmark work of cultural criticism The Long Revolution (1961), what factors of selection are at work in the ongoing scholarly and publishing practices of criticism, anthologization, and canonization of gay literature? Of the two companion chapters I recently researched, one (6000 words) was on American gay and lesbian literature from 1980 to the present and one (8000 words) was on American gay and lesbian literature from 1914 to the present. ${ }^{7}$ Deeming what is "representative" from the vast wealth of what might be construed as American gay, lesbian and queer literature in such brief entries has concentrated my mind on questions of how texts that constitute a tradition are valued and selected.

There is an important and obvious difference between the constitution of an American gay literary tradition and a New Zealand one, in that while the United States has, as I've just noted, a "wealth" of texts that might be included, the field of New Zealand literature is characterised by an apparent paucity of suitable candidates. In the introduction to what is still the signature anthology of gay writing from Aotearoa New Zealand, Best Mates (1997), Peter Wells presents New Zealand literary history as marked by absence, repression, and subterfuge with regard to 
the issue of homosexuality. In the United Kingdom and the United States - the two nations to which New Zealand writers most often looked for inspiration and comparison-an avowedly gay literature developed in the late 1970s as an effect of gay liberation, and its politics of openness and pride. This literature, while it described and helped fashion the dramatically changed gay lifeways of the post-liberation period, also had precedents in the range of early and mid-century fiction and drama that explicitly addressed homosexual experience. By contrast, for the new gay writers of New Zealand of the late 1970s and 1980s looking back at their literary past, Wells writes, "it was as if there was a tabula rasa. Nothing existed before us (as far as we knew). There was simply an eternity of blank." ${ }^{\prime 8}$ Wells continues that "in many ways it appears to me, a contemporary of this period, that the post-liberation works of New Zealand fiction emerged without any sense of sequence, and as much in relation to changes in society, politics, and fiction outside New Zealand as to forces and fiction within" (27). Wells's introduction is probably the most substantive attempt to map a New Zealand gay literary tradition to date, but it is an attempt that is not only compromised by an apparently unpromising history (a seeming "eternity of blank") but also shot through with a tension that is perhaps intrinsic to the attempt to build a national literary tradition of any kind - a tension between attention to literary progress within a nation's borders and registration of the global flows of literary and cultural change. The inescapability of global contexts is one of the strong suggestions of the transnational turn within literary studies, which has thrown into question the usefulness and indeed the validity of treating national origin as a prime focus of literary research. ${ }^{9}$ Adjacent to or overlapping with the scholarly field of world literature, the study of literary transnationalism offers essential purchase on the particular case of $A$ Way of Love.

While several of Courage's novels have New Zealand settings, A Way of Love, a frank treatment of a gay love affair set in London, never mentions Courage's country of birth. In this respect, his novel exemplifies the process of transnational transplantation or "expatriation" common to early and mid-century Antipodean writers of Courage's generation. ${ }^{10}$ More particularly, I would like to suggest, the metropolitan setting of A Way of Love indicates the orientation toward the transnational for gay male Antipodean writers, including, along with Courage, the Australians Patrick White, Martin Boyd, and Sumner Locke Elliott. ${ }^{11}$ But that this elaboration of transnational flow need not be simply a one-way process - in which the Antipodean gay author's national origins are effaced in his assimilation to the putatively more sophisticated gay culture of the metropole - is illustrated in the case of A Way of Love by that novel's dramatic New Zealand career. Briefly available for purchase in New Zealand on its first publication, the novel was effectively banned by the Inter-Departmental Committee, a tribunal consisting of Customs, Justice and Crown Law representatives in 1961, after a referral by the Assistant Commissioner of Police (the book did, however, remain available in some libraries, despite the threat of prosecution carried in the Inter-Departmental Committee's edict). ${ }^{12}$ For Wells, this turn of events epitomizes the repressive tenor of New Zealand literary culture in the pre-liberation era. Seeking, as he states in his introduction to Best Mates, to trace "a few imaginary ancestors," Wells finds himself for the most part frustrated. Gay fiction, which he defines as "fiction in which a homosexual presence is not consciously or subconsciously excluded" (7), is barely there before the 1980s, and the attempted extirpation of A Way of Love is for Wells an all-too-representative instance of mid-century New Zealand's intolerance of the visibility and in fact the very existence of sexual minorities. Indeed, in styling his attempt to map a New Zealand gay literary tradition as a quixotic search for "imaginary ancestors," Wells's survey registers at its inception the particular elusiveness of gay New Zealand "forefathers" in particular, as well as the arbitrariness of literary tradition-making in general. That the reluctance to admit homosexual associations in pre-liberation New Zealand literature had not entirely dissipated even by the 1990s is indicated in Wells's introduction by 
his noting that both the Courage estate along with the estate of another writer, Charles Brasch, refused permission to reprint their work in Best Mates.

Wells's use of the term "imaginary ancestors" resonates with but also departs from Raymond Williams' use of the figure of the ancestor in his magisterial commentary on the "selective tradition" in The Long Revolution. Selective tradition, Williams argues, connects "lived culture and period cultures"; and it is a process of change - "a continual selection and re-selection of ancestors." 13 Williams is alert not only to the changeable, presentist orientation of the selective tradition but also to the "many kinds of special interest, including class interests" that govern the building of tradition (51). Williams writes before the idea of the canon takes on its contemporary resonance, though his effort to describe the political implications of traditionbuilding is a perhaps insufficiently acknowledged precursor argument. Williams' notion of the selective tradition is interestingly both athwart and relevant to the current literary critical moment, when the fervour of the canon wars of the 1980s and 1990s has died down, and it's generally accepted that there is a plurality of possible worthwhile objects of study, and a plurality of traditions (even if this principle is unevenly applied to the actual teaching of literature). The moves to world literature, to transnationalism, and to multiculturalism as focuses of literary study, as well as the thriving scholarly subfields examining pulp, middlebrow, and popular literature exemplify the changed situation. By contrast, Williams cleaves to the assumption of a single, unified tradition, even if he is aware that such tradition is produced by socially grounded interests rather than the disinterested recognition of historically transcendent value, as is the case for the remaining defenders of the "Western canon." But when a novel is censored or it goes out of print, its chances to enter any kind of canon or any kind of tradition recede or disappear entirely. ${ }^{14}$ And both these fates befell $A$ Way of Love. In what sense, then, and in what ways can $A$ Way of Love be understood meaningfully as part of a tradition or counter-canon?

For Wells, the value of reclaiming Courage's novel is to instate a sense of a continuing, if intermittent, homosexual heritage that offers an alternative to, even as it is interwoven with, the received, masculinist history of New Zealand letters. Similarly, but in a more definitely academic-political vein, Christopher Burke, in an essay about the "pre-liberation literary worlds" of Courage, Frank Sargeson, and Bill Pearson, locates the work of these New Zealand writers as forms of resistance to the "heteronormative regimes of power" that "queer the historical register." 15 For Chris Brickell, in Mates and Lovers, his invaluable history of gay New Zealand, Courage's novel is a landmark text that along with other works of fiction and nonfiction helped instil a sense of collectivity within otherwise isolated homosexuals; Brickell quotes grateful letters to Courage from readers testifying to the enlightening and heartening effects for them of reading $A$ Way of Love. ${ }^{16}$ I want to keep in mind all these perspectives on $A$ Way of Love here, but also to move discussion in a somewhat different direction, beyond its strictly New Zealand context, in order to reflect on the difference that it might make to reinsert a neglected novel like Courage's into current debates about "gay" and "queer" literature (I will parse this distinction presently). ${ }^{17}$

Coincidentally or serendipitously for my purposes, Williams in his formulation of the selective tradition illustrates its operations through reference to "the novels of the last decade," that is, the 1950s - the decade at the end of which Courage's book appeared. Williams argues that the process of selection that goes to make up tradition "begins within the period itself." "In general," he continues, "this selection will reflect the organization of the period as a whole, though this does not mean that the values and emphases will later be confirmed." This is clear enough when we are at a distance from a given period, but, says Williams, "we never really 
believe it about our own" (50). Williams exemplifies his point by noting that:

Nobody has read all the English novels of the nineteen-fifties; the fastest reader, giving twenty hours a day to this activity alone, could not do it. Yet it is clear, in print and in education, not only that certain general characteristics of the novel in this period have been set down, but also that a reasonably agreed short list has been made, of what seem to be the best and most relevant works.... Yet we can surely be quite certain that, once the 1950s have passed, another selective process will be begun. As well as reducing the number of works, this new process will also alter, in some cases drastically, the expressed valuations. It is true that when fifty years have passed it is likely that reasonably permanent valuations will have been arrived at, though these may continue to fluctuate. $(50-51)^{18}$

For my purposes, Williams's argument here raises several provocative points. The process of selection as he describes it here, though he emphasizes that it will not remain static but shift into a process of revisionist reselection, refers, as I noted above, to a single tradition. But his claims are still galvanizing for my concern with a specifically gay tradition, or countertradition; the quoted passage from Williams opens up the question of how we regard novels that make homosexuality central from the 1950s, now that more than "fifty years have passed" since most of the novels of that decade were published. Williams notes that the selective tradition "creates, at one level, a general human culture; at another level, the historical record of a human society; at a third level, a rejection of considerable areas of what was once a living culture" (51). If Williams's account of tradition as creating "a general human culture" might set off alarm bells for many scholars after the critique of the canon, the other two operations of the tradition that he describes are no doubt uncontroversial. Courage's novel is barely discussed outside of New Zealand contexts, and thus we could say, according to the terms of Williams's schema, it has been "rejected" from the tradition of the mid-century novel. When Courage's novel is considered, it is for its "historical" importance for New Zealand gay writing and gay culture. I agree on its historical importance but I want to leverage this aspect of the novel into a consideration of the current standards of evaluation in queer literary studies. I want to think about what happens if I provisionally and unilaterally usher $A$ Way of Love into the Anglophone transnational gay tradition. A neglected novel like $A$ Way of Love is useful, I will suggest, for how we conceive of a gay literature in the contemporary moment and how that might be thought through. Its transnational status also offers a corrective to the American bias of queer literary studies.

My interest in gay literary tradition-making, as I've indicated, was prompted by the composition of those two companion chapters on American gay and lesbian literature. In preparing the chapters, I was struck, reading around relevant queer scholarship, by the privileging of the "queer" over the "gay" and the concomitant privileging of early twentiethcentury modernism by comparison with mid-century realism. That the queer is privileged over the gay within queer studies is probably no news to scholars in the field of sexuality studies, or indeed to many less familiar with the field. Nevertheless, reading other queer scholars who had produced chapters on, for instance, the gay American novel, drove home to me how thoroughly this bias was translated into aesthetic judgment and consequently into a selected list of "the best and most relevant" texts, to use Williams's phrase.

But what do I mean here by distinguishing between the queer and the gay? Queer studies, which emerged in the early 1990s and which is currently the dominant paradigm in sexuality research in the humanities, emphasises the historical contingency and the fluidity of sexual identities. In its initial formulation, queer studies (or queer theory) sought to revise the lesbian and gay 
studies that had made important contributions to history, literary criticism and other academic areas in the 1970s and 1980s, and which drew its intellectual energy from the liberationist analysis of the structural oppression of gay and lesbian people and the countervailing force of openness and pride. Taking Foucault's History of Sexuality Volume 1 (1976) as its ur-text, queer studies proposes a quite different, and indeed non- or anti-liberationist account of samesexuality. It sees sexual identity categories like gay or lesbian as examples of what Foucault sees as the transformation of sex "into discourse, a technology of power, and a will to knowledge" that develops slowly over the last three hundred years, and that by the early twentieth century has taken decisive hold in the "liberal" societies of the West-with liberalism understood as a permissive ruse masking the disciplinary force of what Foucault calls power/knowledge. ${ }^{19}$ "Queer" is a somewhat incoherent concept, but one of its primary theoretical functions has been to mark or to gesture toward various resistances to the sexual identity categories of power/knowledge. In this permutation, queer names moments or movements of submerged or camouflaged resistance, usually though not exclusively associated with same-sexuality, that are contrasted with the open and assertive confrontation of gay and lesbian identity; hence the queer critique of visibility that I noted above. While Foucault also notes that homosexual identity categories can act as counterdiscursive forms under which the individuals constituted by them may struggle against disciplinary social forces, the tendency of queer studies to downplay this capacity of sexual minority identities leads to the valorization and indeed the celebration of contingency, fluidity, and instability. This bias has led to concentrations of activity in queer literary studies on the nineteenth-century period that predates modern sexual identity categories, and on early twentieth-century modernism, which tends to elaborate gendered and sexual fluidity.

Again and again in queer literary studies, figurations of sexuality in terms of elusiveness, opacity, and ellipsis, are favourably contrasted with the affirmation of the homo/hetero binary. Robert Caserio, another such scholar, praises the putatively liberatory effect of a modernist "unregulated eros"- eros unregulated, that is, by sexual identity categories. ${ }^{20}$ And Christopher Looby contrasts the "utopian" exploration of gendered and sexual fluidity of early twentiethcentury experimental literature with the implicitly less interesting literature of mid-century that tends to take "the homosexual category of person for granted." 21 This utopian tendency within queer literary criticism exemplifies a general tendency toward utopian thinking in queer theory. Here and elsewhere I contend that the utopianism of queer thought has had its analytic and political purchase dulled in the routinisation of its announcement. I am interested in challenging the privileging of utopian instability in queer studies, and in drawing out the counterdiscursive capacity of "gay" and "lesbian"; and I propose now a reading of Courage's novel that dovetails with this project.

A Way of Love centres on a love affair between the narrator-protagonist, Bruce, and a younger man, Philip; the affair ends unhappily, with Philip leaving Bruce. Tensions within the relationship are generated not so much by the age difference between the two men as by the reluctance of the younger man to engage with the homosexual subculture-more specifically, to engage with the architect's friends who synecdochally stand in for that subculture. Bruce reports Philip's insistence that

our affair was strictly something between ourselves, a matter à deux. He had implored me not to involve him with my friends, or more precisely my friends of an understood kind. He pictured them in fact as scornful, rapacious, terrifying: he would instantly find himself branded as "one of them, because of $u s$ "; he wanted to be always alone with me and had more or less forbidden me even to speak to those "types" ... whose 
crime was that they had known me in the past and who might still be capable of beguiling me away from him at the drop of a hat. ${ }^{22}$

Though Philip eventually relents and does engage in some awkward socializing with Bruce's gay friends, he continues to resist being "branded" as "one of them," i.e., homosexual, in the eyes of those friends and by implication in the eyes of the larger social world; when he leaves Bruce, he does so with the stated intention of someday marrying a woman. It is the seemingly inexorable movement from being one of "us"-one member of a male couple - to being one of "them," an easily identified homosexual "type," that Philip wishes to forestall. Opposing his coupledom with Bruce to the world of the subculture in this way, Philip attempts to reject homosexual identity while enjoying homosexual love. For his part, Bruce is largely content for much of the narrative to luxuriate with Philip in their coupledom. Yet as an attached member of the subculture, he also feels himself to be in "voluntary exile from my kind" (150). If Bruce's troping of coupledom as voluntary exile (expatriation?) metaphorises the subculture as a nation, elsewhere he figures it as a world - "the world of my kind" (222), "the little world I shared with others of my kind" (238), "our world" (246). And the novel devotes considerable space to delineating those "others" of Bruce's "kind," providing a taxonomy of the "types," as Philip would have it, who inhabit the gay world: the unabashed camp queen, the desirable youth on the make, the middle-aged man who cloaks his sexuality in marriage to a woman, and so on. A world within a world, the subculture may not offer Bruce anywhere near the affective and sexual intimacy of life "à deux" with Philip, but it is an essential resource of "sociability" (246).

As Bruce puts it, in the midst of his "happiness" with Philip, he finds himself "unreasonably anxious not to lose the wider companionship of my kind," and:

suffering a certain homesickness for the company of those who lived, as I did or had done, in more or less full self-acceptance of their own natures as members of what I may call without exaggeration our immense league-members who were scattered and for the most part strangers to one another, but who shared a common erotic compulsion, a common form of social difficulty, often a common glossary, and who rejoiced in the anonymity of cities. (145)

The gay world (or "league," as Bruce puts it here) is "scattered," yet united by the shared experience of same-sex desire and its oppression. Implicitly transnationally dispersed, the gay world, as Bruce eloquently describes it, doesn't look so different from the gay world of "scattered and isolated individuals" that Elam describes - with the exception, it seems, of visibility. Elam's romanticisation of this world relies on the assumption of an outlawry that excludes the possibilities of visibility and banality. When outlawed, Elam's argument implies, gay men necessarily strove together in a collective project of culture-making (or worldbuilding). And, indeed, I think that a work like $A$ Way of Love is invaluable evidence of the way in which gay literature and gay life interacted to produce forms of homosexual collectivity and solidarity in the pre-liberation period. Yet the picture of the gay world offered is not the anti-normative haven imagined by Elam. Elam's account of the pre-digital, pre-globalised subculture illustrates, albeit in a relatively muted register, the queer utopianism I described above: the investment of queer studies in "the idea of an impossible-because absolutewithdrawal from the social," as Heather Love puts it in a recent revisionary account of the fraught relation of queer theory to the "deviance studies" of mid-century social science. ${ }^{23}$ Love argues that social science research on homosexuality in the postwar period, "by shifting the frame from individual pathology to social organization[,] ... built a portrait of homosexual life as ordinary and rule-bound rather than anomic and exotic." ${ }^{24}$ Queer critics, Love contends, 
have relied on the sociological category of deviance, embracing it, however, "not as an inevitable counterpart to conforming behavior and an integral aspect of the social world, but ... as a challenge to the stability and coherence of that world." ${ }^{25}$ Love's account of the way mid-century social science helped promote a sense of gay subcultural life as "ordinary" - as an integral, if particular, part of the larger social world, with its own conventions and patterns of interaction-offers a useful perspective on a middlebrow novel like Courage's which, appearing at the time that the social-scientific view was emerging, has no investment in the "anomic and exotic" representation of homosexuality, but is similarly interested in forging a sense of the ordinary, yet particular, cast of gay sociality.

In a self-reflexive moment, in the novel Bruce and his friends wistfully imagine a gay or queer literature "that treats us as human beings like other people." A hypothetical novel that treats homosexual love frankly is, however, spoken of as "dynamite to the English.... Nobody but our dear Customs officials would have been allowed to read a word of it" (111). Ironically forecasting its own censored fate - the novel proved to be dynamite to New Zealanders rather than to the English, which is not to say that the English welcomed it either-A Way of Love both elaborates the felt need for a gay-affirmative literature as well as tentatively embodying it. Indeed, as an apparently widely marketed novel (it was published in both the US and the UK), if not a big seller, the novel contributed to the increasing visibility of gay lifeways that was already under way in the 1950s and that was to accelerate markedly in the $1960 \mathrm{~s}^{26}$ The conceit of A Way of Love's narrative is that it is a cathartic act of writing by Bruce, an act in which he is encouraged by James Caspar, a novelist and minor member of the cast of characters that represent the "little world" of London's gay subculture. (The novel's self-reflexivity here is compounded by the closeness of the name of its novelist character, James Caspar, to his author, James Courage. $)^{27}$ In response to Bruce's objections that the story might be "no more than the chronicle of an erotic relationship," and "too special - to ephemeral," Caspar asserts: "Why shouldn't one write of an erotic relationship? In any case nobody can say that your affair with Philip was only or entirely that. Far from it" (249). And the story as written is "far from" only or entirely about the love affair, instead setting out a compelling account of the tensions and connections between gay identity, gay erotic intimacy, and the gay subculture.

If Philip rejects the idea of becoming homosexual- "one of them"-Bruce remains steadfastly allied to the identification. And in fact Philip's attempted breakaway from homosexual identification is cast in doubt in the final chapter, in which he asks to return to live in Bruce's house, a request that Bruce refuses, as he thinks that the younger man "having won a difficult independence for himself ... should continue to order his own life, weaned from mine," and also that "in writing this history of our affair ... I had already to some extent worked him out of my system" (252). For all the tensions and blockages that he experiences in his interactions with his gay friends, Bruce's story makes clear the affirming capacities of the subculture. In his description of his "homesickness" for the gay world, the narrator-protagonist definitely and even perhaps defiantly marks himself as a gay or queer man - as thoroughly "captured," in Foucauldian terms, by those sexual identity categories, which, in the world of the novel, are interchangeable, by contrast with their divergent trajectories in recent academic theory. ${ }^{28}$ For Foucauldian queer studies, such capture is more or less to be regretted; and for queer literary studies specifically, a novel like A Way of Love, with its preoccupation with the fixed category of homosexual identity and with its subcultural expressions, is no doubt of limited interest. Yet as I hope to have demonstrated, admitting a neglected, middlebrow, realist novel like $A$ Way of Love back into our account of the gay tradition enables a more nuanced account of "how we got here," and a partial corrective to the queer utopianism of what Love calls "an impossiblebecause absolute-withdrawal from the social." Additionally, if the novel carries no specific 
New Zealand content, attention to its New Zealand career stands as a salutary caution against the Foucauldian conception of sexual identity as a form of coercive power/knowledge in that it so dramatically illustrates the limitations that may be applied to the identity categories that, according to queer theory, "liberal" society allows to flourish. I would suggest that the treatment in New Zealand of Courage's novel in fact typifies, albeit in extreme form, the strong tendency of mid-century liberal culture to repress gay expression. Consideration of this novel in its transnational aspect, then, and adding it to our "tradition" of gay texts worth reading and thinking about, helps reshape our understanding of the counterdiscursive force of gay identity, gay literature, and the gay world.

\footnotetext{
${ }^{1}$ J. Daniel Elam, "The World of Gay Lit," Public Books (16 October 2017). Web. Accessed 1 March, 2018. "Disciplinary rallying point": Emily Apter, Against World Literature: On the Politics of Untranslatability (London: Verso, 2013), 1. For a discussion of the interrelations between "world literature" as the marketization of cultural differences and as a field of scholarly enquiry, see Simon During, Exit Capitalism: Literary Culture, Theory and Post-Secular Modernity (New York: Routledge, 2009), 57-58.

2 Judith Butler, "Imitation and Subordination," in Inside Out: Lesbian Theories, Gay Theories, ed. Diana Fuss (New York: Routledge, 1991), 16.

${ }^{3}$ Lee Edelman, Homographesis: Essays in Gay Literary and Cultural Theory (New York: Routledge, 1994), 10.

${ }^{4}$ Leo Bersani, Homos (Cambridge: Harvard University Press, 1995), 11-12.

${ }^{5}$ The Stonewall Inn riots saw drag queens, lesbians, and gay male bar patrons fight back against police harassment for two nights in July 1969. The popular understanding of the riots as the sudden, disruptive beginning of gay liberation has long been challenged by historians of sexuality, who have outlined the complex foundations of the liberation moment, including the efforts of the pre-liberation homophile rights movement. See especially John D'Emilio, Sexual Politics, Sexual Communities: The Making of a Homosexual Minority in the United States, 1940-1970, 2nd ed. (Chicago: University of Chicago Press, 1998). Moreover, in an essay emphasizing the "global" aspects of gay culture, it is worth stressing the US-centrism of most discussions of liberation; even confining ourselves to "the West," it's evident that European countries had distinctly different histories from the US, with many seeing significant increases in social tolerance and decriminalization of male homosexual acts well in advance of America. However, the American liberationist emphasis on openness and pride has had massive influence worldwide in the post-Stonewall period and, for this reason, I assume in this essay that a major shift in the political and cultural status of homosexuality took place "around 1969." ${ }^{6}$ My discussion of Elam might seem to take an overly forensic approach to a brief online essay adopting a crossover academic/general interest mode of address. I mean, however, not primarily to criticize specific lapses in rigour on Elam's part but to bring out the way his review symptomatizes certain currents in queer literary studies with which I take issue in this essay.

${ }^{7}$ Guy Davidson, "The Time of AIDS and the Rise of 'Post-Gay," in The Cambridge Companion to American Gay and Lesbian Literature, ed. Scott Herring (New York: Cambridge University Press, 2015), 139-54; "Gay and Lesbian Literature," in The Blackwell Companion to American Literature, ed. Michael Soto, vol. 3 (New York: Wiley-Blackwell, forthcoming).

${ }^{8}$ Peter Wells, "Introduction," in Best Mates: Gay Writing in Aotearoa New Zealand, ed. Peter Wells and Rex Pilgrim (Auckland: Reed, 1997), 26. Subsequent references are given parenthetically in the text.

${ }^{9}$ For a useful introduction (albeit one anchored in American academic practice), see Paul Jay, Global Matters: The Transnational Turn in Literary Studies (Ithaca: Cornell University Press, 2010).

${ }^{10}$ For discussions of Antipodean literary expatriation, see Bruce Bennett and Anne Pender, From a Distant Shore: Australian Writers in Britain 1820-2012 (Melbourne: Monash University Press, 2012); Helen Bones, The Expatriate Myth: New Zealand Writers and the Colonial World (Dunedin: University of Otago Press, 2018); Peter Morton, Lusting for London: Australian Expatriate Writers at the Hub of Empire (London: Palgrave Macmillan, 2011).
} 
${ }^{11} \mathrm{My}$ interest in queer Antipodean writers and transnationalism has been spurred by Shaun Bell, "Writing the Hyphen: Queer Masculinities, Nationalism, and the Literary Transnation," (PhD thesis, University of New South Wales, 2017), which examines all of the Australian writers mentioned. Boyd (1893-1972) lived in London and Rome for most of his adult life; White (1912-90) lived in London and Cairo in the 1930s and 1940s; Elliot (1917-91) migrated to New York in 1948. My emergent concern with queer literary transnationalism intersects with an important strand of queer cultural studies scholarship on cosmopolitanism and globalization; see, e.g., Arnaldo Cruz-Malavé and Martin F. Manalasan, Queer Globalizations: Citizenship and the Afterlife of Colonialism (New York: New York University Press, 2002); and Jasbir K Puar, ed., "Queer Tourism: Geographies of Globalization," special issue, GLQ 8, nos. 1-2 (2001).

${ }^{12}$ See Wells, 'Introduction," 23-24. I'm grateful to an anonymous reader for information about the book's continuing availability in libraries.

${ }^{13}$ Raymond Williams, The Long Revolution (London: Chatto and Windus, 1961), 49, 52. Subsequent references are given parenthetically in the text.

${ }^{14}$ My sense of what constitutes a canon (if not a tradition) relies on the influential, opposed arguments of John Guillory, in Cultural Capital: The Problem of Literary Canon Formation (Chicago:

University of Chicago Press, 1995) and Franco Moretti, in "The Slaughterhouse of Literature," in Distant Reading, 63-90 (London: Verso, 2013). While Guillory argues that the canon is produced by academics through their selection of what texts are taught, Moretti argues that the reading market makes the canon, with generations of readers keeping certain texts alive, which are then converted into a canon of, say, the eighteenth-century novel. In a slight concession to Guillory's argument, Moretti does, however, contrast an "academic canon," which may promote texts little read outside of the university (such as metaphysical poetry) with a "more significant" "social canon" of the novel; see Moretti, Distant Reading, 68n4. For my purposes, the important point is that both these models of the canon require that texts be readily available - something that is not the case for a neglected, out-ofprint gay novel like A Way of Love.

${ }^{15}$ Christopher Burke, "Turning the Inside Out: Pre-Liberation Literary Worlds in the Works of Frank Sargeson, James Courage and Bill Pearson," Journal of New Zealand Literature, no. 26 (2008): 96.

${ }^{16}$ Chris Brickell, Mates and Lovers: A History of Gay New Zealand (Auckland: Godwit, 2008), 256.

${ }^{17}$ For a recent discussion that contrastingly places A Way of Love in an English gay literary tradition of "critically disregarded" mid-century novels, see Martin Dines, "Bringing the Boy Back Home: Queer Domesticity and Egalitarian Relationships in Postwar London Novels," Literary London Journal 10, no. 2 (2013), accessed 2 October 2017.

${ }^{18}$ There is an anticipation here of Moretti's celebrated argument in "The Slaughterhouse of Literature"- one reason why I suggested above that Williams's importance for later discussions of the canon has perhaps been insufficiently acknowledged. In that essay, Moretti begins by noting that most novels of the nineteenth century are forgotten, "slaughtered" by readers who keep a bare handful alive, which are subsequently taken up into the academic canon.

${ }^{19}$ Michel Foucault, The History of Sexuality, Volume 1: An Introduction, trans. Robert Hurley (Harmondsworth: Penguin, 1990), 12. For an important critique of the "paranoid" queer-Foucauldian critique of liberal society, see Eve Kosofsky Sedgwick, "Paranoid Reading and Reparative Reading; or, You're So Paranoid, You Probably Think This Introduction is about You," in Novel Gazing: Queer Readings in Fiction, ed. Eve Kosofsky Sedgwick (Durham: Duke University Press, 1997), 1720.

${ }^{20}$ Robert Caserio, "Queer Modernism," in The Oxford Handbook of Global Modernisms, ed. Mark Wollaeger and Matt Eatough (New York: Oxford University Press, 2012), 201.

${ }^{21}$ Christopher Looby, "The Gay Novel in the United States, 1900-1950," in A Companion to the Modern American Novel, 1900-1950, ed. John T. Matthews (Chichester: Wiley-Blackwell, 2009), 433.

${ }^{22}$ James Courage, A Way of Love (New York: Putnam, 1959), 107. Subsequent references are given parenthetically in the text.

${ }^{23}$ Heather Love, "Doing Being Deviant: Deviance Studies, Description, and the Queer Ordinary," differences 26, no. 1 (2015): 89.

${ }^{24}$ Ibid., 76.

${ }^{25}$ Ibid., 77.

Journal of New Zealand Studies NS26 (2018), 34-44 https://doi.org/10.26686/jnzs.v0iNS26.4840 
${ }^{26}$ For a discussion of the increasingly open discussion and representation of homosexuality in the 1960s, see D'Emilio, Sexual Politics, 134-48. Again, the perspective is American of course, but the changes D'Emilio traces were mirrored elsewhere in the Anglophone world. Published in hardback by Putnam in New York and Jonathan Cape in London, A Way of Love does not appear, as far as I can tell, to have been published as a paperback, despite its eminent suitability for the "gay pulp" market that started forming in the late 1950s; see, e.g., Drewey Wayne Gunn and Jaime Harker, eds., 1960s Gay Pulp Fiction: The Misplaced Heritage (Amherst: University of Massachusetts Press, 2013).

${ }^{27}$ Wells notes that Caspar "is a masque, one feels, for Courage himself." "Introduction," 21.

${ }^{28}$ In the novel, homosexual men are characterized as queer or associated with queerness on pp. 110, $135,215,2161$; and characterized as gay or associated with gayness on pp. 51, 56, 141, 176, 194, 221, 227. 